\title{
PENGARUH MODEL KEPEMIMPINAN DAN MANAJEMEN TERHADAP KINERJA PERPUSTAKAAN PERGURUAN TINGGI NEGERI DAERAH ISTIMEWA YOGYAKARTA
}

\author{
By Lasa Hs *) ;Yéremias T.Keban**); Ratminto **)
}

\begin{abstract}
The leadership and managerial style of librarians are influential to staff performance, job satisfication, understanding of vision and mission of the library and human resource development. The leadership and managerial style of teaching staff are influential to job satisfication, overall library planning, and the understanding of vision aand mission of the library. Double position (chief of university library and academic staff) causes inefficiency an ineffectiveness due to limited knowledge on librarianship and management.
\end{abstract}

Keywords: Library Management; Library Leadership

*). Librarian of Gadjah Mada University Library

**) Teaching Staff of the Faculty of Political and Social Science, Gadjah Mada University

\section{ABSTRAK}

Kepemimpinan dan manajerial sangat diperlukan dalam pengelolaan perpustakaan dan pusat-pusat informasi. Dengan adanya kepemimpinan dan manajerial yang baik, maka seluruh aktivitas akan diarahkan pada pencapaian tujuan.

Untuk lebih meningkatkan fungsi dan kinerja perpustakaan Perguruan Tinggi Negri Daerah Istimewa Yogyakarta, pimpinan perpustakaannya terdiri dari pustakawan dan dosen. Saat ini (tahun 2000/2001) terdapat 2 (dua) perpustakaan perguruan tinggi negeri DIY yakni UPT Perpustakaan IAIN Sunan Kalijaga dan UPT Perpustakaan ISI Yogyakarta dipimpin oleh pustakawan. Kemudian 2 (dua) perpustakaan perguruan tinggi yang lain yakni UPT Perpustakaan UGM dan UPT Perpustakaan UNY dipimpin oleh dosen.

Dalam penelitian ini ingin diketahui sejauh mana para pimpinan perpustakaan PTN DIY itu menerapkan fungsifungsi manajemen, sejauh mana pengaruh kepemimpinan dan manajerial mereka terhadap kinerja perpustakaan yang mereka pimpin. Juga ingin diketahui kriteria apa saja yang diperlukan dalam pengangkatan pimpinan perpustakaan tersebut

Dari hasil penelitian ini dapat diungkapkan bahwa para pimpinan perpustakaan PTN DIY belum menerapkan fungsifungsi manajemen secara optimal. Kemudian kepemimpinan dan manajerial pustakawan berpengaruh pada kepedulian sosial, peningkatan kinerja, kepuasan kerja, pemasyarakatan visi dan misi, dan peningkatan sumber daya manusia. Kemudian kepempimpinan dan manajerial dosen/rangkap jabatan berpengaruh pada kepuasan dan peningkatan kerja, perencanaan pengembangan perpustakaan, dan pemasyarakatan visi dan misi. Bahkan sistem rangkap jabatan dinilai kurang efektif dan kurang efisien. Hal ini disebabkan keterbatasan kemampuan manajerial, dan kurangnya jiwa kepemimpinan.

Katakunci: Manajemen Perpustakaan; Kepemimpinan Perpustakaan

*). Pustakawan Universitas Gadjah Mada

**) Staf Pengajar Fisipol Universitas Gadjah Mada 


\section{LATAR BELAKANG}

Pimpinan merupakan faktor penentu dalam upaya pencapaian tujuan suatu organisasi atau lembaga. Kualitas pemimpin menentukan keberhasilan organisasi/lembaga yang dipimpinnya. Sebab pemimpin yang baik antara lain adalah mereka yang mampu mengelola organisasi, bisa mempengaruhi orang lain secara konstruktif, menunjukkan jalan, perilaku, dan tindakan yang benar yang harus dikerjakan bersama-sama. Oleh karena itu pemimpin harus mampu mengantisipasi perubahan-perubahan yang terjadi, mengoreksi kelemahan-kelemahan, dan membawa suatu organisasi/lembaga ke sasaran yang jelas dalam jangka waktu tertentu.

Dalam kelompok masyarakat yang disana terdapat kerja kolektif, diperlukan kepemimpinan dan pemimpin untuk mengefisienkan dan mengefektifkan kegiatankegiatan. Pemimpin-pemimpin yang baik adalah mereka yang mau mengakui bakat, keahlian, spesialisasi, inisiatif, dan*partisipasi pengikutnya (anak buah, bawahan, karyawan) untuk berinisiatif dan bekerjasama secara kooperatif. Pemimpin seperti inilah yang mampu menyejahterakan bawahan dan sekaligus sanggup mempertinggi produktivitas dan efektivitas usaha bersama.

Kepemimpinan adalah masalah hubungan antara yang dipimpin dan pemimpin. Dalam hal ini kepemimpinan pada umumnya berfungsi atas dasar kekuasaan pemimpin untuk mengajak dan menggerakkan orang lain untuk melakukan kegiatan dalam rangka pencapaian tujuan tertentu.

Pemimpin yang mampu menggerakkan anggotanya untuk mencapai tujuan organisasi/lembaga (perpustakaan) dapat dikatakan telah memiliki kepemimpinan yang efektif. Dalam kenyataannya efektivitas itu masih dipengaruhi oleh beberapa faktor seperti; faktor waktu, faktor sumber-sumber yang digunakan, faktor tingkat produktivitas, dan lain-lain (Hadari Nawawi, 2000: 13). Tingkat efektivitas itu sebenarnya merupakan hasil bersama antara usaha pemimpin dan yang dipimpin. Pemimpin tidak dapat berbuat banyak tanpa partisipasi yang dipimpin. Demikian pula halnya dengan yang dipimpin, mereka tidak akan efektif dalam melaksanakan tugasnya tanpa adanya pengarahan, pengendalian, dan kerjasama yang baik dengan pemimpin.
Pemimpin yang efektif akan selalu berusaha mengembangkan situasi sosial yang bersifat kebersamaan yang mampu memberikan dukungan positif terhadap keputusan yang telah ditetapkan. Untuk itu seorang pemimpin perlu memperhatikan dua dimensi interaksi sosial yakni dimensi pengarahan/direction dan dimensi dukungan/ support anggota selaku yang dipimpin. Berdasarkan kedua dimensi ini, maka kepemimpinan memiliki fungsi-fungsi; instruktif, konsultatif, partisipatif, dan pengendalian (Hadari Nawawi, 1993: 143).

Perpustakaan sebagai organisasi/lembaga informasi yang dalam proses manajemennya terdiri dari perencanaan, pengorganisasian, pengarahan, pembiayaan, dan pengawasan yang dalam pelaksanaannya memerlukan interaksi antara pemimpin dan yang dipimpin. Hubungan kedua elemen ini mempengaruhi kinerja perpustakaan.

Kinerja perpustakaan dipengaruhi oleh kepemimpinan kepala perpustakaan dalam memimpin dan memenej perpustakaan yang dipimpinnya. Sebab dalam proses kepemimpinan tidak dapat lepas dari motivasi sebagai pendorong. Seorang pemimpin terdorong oleh motivasi kekuasaan, dan yang dipimpin didorong oleh motivasi tertentu dan tertuju pada kebutuhan masing-masing.

Perpustakaan perguruan tinggi memiliki kedudukan strategis dalam menunjang tridharma perguruan tinggi yang bersangkutan, maka perpustakaan merupakan perangkat pelengkap di bidang pendidikan, penelitian, dan pengabdian masyarakat di luar fakultas, jurusan, dan laboratorium (Peraturan Pemerintah No. 60 tahun 1999 pasal 34). Adapun pimpinan unsur penunjang diangkat dan bertanggung jawab langsung kepada pimpinan perguruan tinggi yang bersangkutan (pasal 34 ayat 3 ). Sedangkan tenaga penunjang akademik terdiri dari; peneliti, laboran, dan teknisi sumber belajar. Adapun tatacara pengangkatan dan wewenang tenaga penunjang akademik diatur oleh penyelenggara perguruan tinggi dengan berpedoman pada peraturan perundangan yang berlaku (pasal 107 ayat 1 dan ayat 2).

Pada peraturan tersebut jelas sekali kedudukan perpustakaan, pustakawan, dan kepala perpustakaan dalam lembaga induknya. Bahkan pada perguruan tinggi negeri/ PTN yang telah menjadi Badan Hukum, kepala UPT perpustakaan diangkat menjadi anggota Senat Akademik 
(Peraturan Pemerintah No. 61 tahun 1999 Bab IV pasal 12 ayat 2 b dan Peraturan Pemerintah No. 153 tahun 2000).

Jabatan kepala perpustakaan perguruan tinggi merupakan jabatan struktural yang akhir-akhir ini tidaksaja dijabat oleh pustakawan, tetapi juga dijabat oleh nonpustakawan (dosen, guru, tata usaha, bahkan pensiunan). Hal ini ternyata tidak saja terjadi di perguruan tinggi, tetapi juga di beberapa perpustakaan lain. Zulfikar Zen (2000: 22-23) menyatakan bahwa keadaan tersebut banyak terjadi pada Perpustakaan Nasional, Perpustakaan Perguruan Tinggi, Perpustakaan Umum di lingkungan Departemen Dalam Negeri, dan lainnya.

Pengangkatan seperti ini sekedar posisi administrasi dan akan menimbulkan konflik peran. McConkley (1982: 24) menyatakan bahwa konflik peran ini dirumitkan pula oleh kenyataan bahwa banyak manajer/pimpinan dalam berbagai organisasi/lembaga bahwa yang diangkat sebagai kepala bukan karena ingin, tetapi karena suatu posisi administrasi, alat promosi, kenaikan kompensasi, dan penghargaan bagi peran. Konflik peran ini harus dibenahi.

\section{PERUMUSAN MASALAH}

Dari analisa tersebut, dapat dirumuskan beberapa masalah yang dihadapi oleh perpustakaan-perpustakaan PTN DIY yakni:

1. Apakah para pimpinan UPT Perpustakaan PTN DIY itu telah melaksanakan fungsi-fungsi manajemen dengan baik di perpustakaan masing-masing

2. Apakah manajemen dan kepemimpinan para kepala UPT perpustakaan PTN DIY itu sesuai dengan kondisi perpustakaan yang mereka pimpin.

3. Sejauh manakah pengaruh rangkap jabatan (jabatan struktural kepala perpustakaan dengan jabatan fungsional dosen) terhadap kinerja perpustakaan yang mereka pimpin

4. Seberapa besar pengaruh kepemimpinan dan manajerial pustakawan maupun nonpustakawan terhadap kinerja perpustakaan yang mereka pimpin

\section{TEORI PENELITIAN}

\section{Kinerja Perpustakaan PTN DIY}

Kinerja/performance berarti prestasi yang diperlihatkan (Kamus Besar Bahasa Indonesia, 1994: 503), yaitu suatu hasil kerja yang dicapai oleh seseorang atau kelompok dalam suatu organisasi maupun lembaga sesuai dengan wewenang dan tanggung jawab organisasi sesuai etika dan moral serta tidak melanggar hukum (Suyadi Prawirosentono, 1999: 3).

Tujuan organisasi akan tercapai dengan baik apabila kinerja individu/individual performance itu baik. Kinerja individu itu akan baik apabila mereka memiliki keahlian yang tinggi, bersedia bekerja keras, dan memiliki harapan yang baik. Kemudian baik buruknya kinerja seseorang dipengaruhi oleh faktor internal dan eksternal. Faktor internal itu antara lain berupa: pekerjaan mudah, nasib baik, kerjasama dengan rekan-rekan, dan kepemimpinan yang baik. Sebaliknya kinerja yang buruk itu dipengaruhi oleh faktor internal yang berupa kemampuan yang rendah dan malas bekerja. Adapun faktor eksternal yang mempengaruhi kinerja buruk adalah: pekerjaan sulit, nasib buruk, rekanrekan tidak produktif, dan kepemimpinan yang tidak simpatik (Thomas S. Batman, 1999: 32). Oleh karena itu untuk meningkatkan kinerja individu perlu adanya kemampuan pengelolaan lingkungan kerja yang di dalamnya terdapat interaksi antara pemimpin dan yang dipimpin. Dalam proses pengelolaan lingkungan kerja ini akan terjadi jalinan mata rantai kinerja. Kemudian dalam jalinan ini ditentukan oleh efektivitas keseimbangan antara pekerja individu dan lingkungan. Disamping itu, produktivitas manusia akan dapat diperbaiki dalam jangka panjang dalam proses yang hati-hati dan bijaksana dalam matarantai kinerja itu. Adapun mata rantai kinerja itu meliputi individu-individu, sumber daya, kejelasan tugas, umpan balik, dan akibat-akibat (James T. Batt, 129)Standar kinerja sangat diperlukan dalam suatu organisasi maupun lembaga untuk mengetahui produktivitas. Dalam hal ini perlu diketahui faktor-faktor penyebab menurunnya kinerja dan perlu diungkapkan secara transparan. Sebab pengungkapan penyebab dasar buruknya kinerja merupakan fungsi yang penting dalam suatu organisasi dan ini jarang dilakukan. Banyak organisasi berpegang pada pendekatan 
yang sangat tradisional tentang kinerja ini (Gerald $R$. Ferris , 1999: 233)Disamping itu kinerja karyawan dipengaruhi oleh suasana organisasi. Suasana organisai ini dapat diukur secara kuantitatif dan kualitatif. Ukuran kualitatif dapat diukur dari kriteria tanggung jawab, keragaman semangat kelompok, penghargaan, standar kinerja, dan kejelasan organisasi. Adapun ukuran kuantitatif dapat diukur dari suasana individual, suasana kelompok, dan suasana organisasi. Suasana individu ini bersifat psikologis yakni persepsi kelompok atau sekelompok kerja. Sedangkan suasana organisasi adalah persepsi kolektif dari semua karyawan di dalam suatu unit.

Berdasarkan teori-teori tersebut, dapat diketahui bahwa ternyata banyak faktor yang mempengaruhi kinerja suatu lembaga seperti; motivasi, suasana organisasi/ lembaga, penghargaan, dan lainnya. Dengan berbagai pertimbangan, pengukuran kinerja dalam penelitian ini dibatasi pada peningkatan sumber daya manusia, peningkatan sistem pelayanan, peningkatan penyediaan fasilitas, dan peningkatan suasana yang kondusif.

Sumber daya manusia perpustakaan PTN DIY terdiri dari pustakawan, dosen, arsiparis, tenaga administrasi, dan tenaga fungsional lain yang relevan yang memiliki latar belakang pendidikan sejak sekolah dasar sampai doktor. Tenaga fungsional pustakawan terdiri dari pustakawan pemutihan/impassing, lulusan Diploma, S1, maupun S2 perpustakaan dalam dan luar negeri. Diantara mereka ada yang ditugaskan di luar bidang kepustakawanan seperti bagian keuangan, tata usaha, kepegawaian, dan lainnya. Penugasan seperti ini dapat menghambat sistem manajerial perpustakaan perguruan tinggi.

Pelayanan informasi yang diselenggarakan oleh perpustakaan PTN DIY pada umumnya terdiri dari; pelayanan sirkulasi, referensi, baca di tempat, penelusuran literatur, dan lainnya. Pelayanan tersebut bersifat pasif, dan pelayanan proaktif belum mendapat perhatian.

Fasilitas, sarana, dan prasarana yang sesuai kebutuhan akan membuat pemakai merasa nyaman dan senang dalam pemanfaatan koleksi maupun akses informasi. Sebaliknya fasilitas yang kurang akan membuat kecewa pemakai dan inilah salah satu faktor yang membuat perpustakaan tidak menarik.
Suasana perpustakaan akan mempengaruhi jumlah kunjungan, pemanfaatan koleksi, membaca di tempat, dan peningkatan kinerja petugas. Sedangkan suasana perpustakaan PTN DIY pada umumya belum seperti yang diharapkan. Sebab para pimpinan perpustakaan kurang memperhatikan sistem tata ruang, pencahayaan, pemilihan warna mebeler, dan lainnya.

\section{Kepemimpinan}

Kepemimpinan sebagai salah satu fungsi manajemen telah banyak didefinisikan oleh para pakar sesuai persepsi mereka. Dalam hal ini Stoner (dalam T. Hani Handoko, 1993: 294) menyatakan bahwa kepemimpinan adalah suatu proses pengarahan dan memberikan pengaruh pada kegiatan-kegiatan dari sekelompok anggota yang saling berhubungan.

Kepemimpinan berbeda dengan manajemen. Kepemimpinan merupakan jenis kegiatan manajerial terbatas yang memusatkan perhatian pada interaksi antar pribadi (antara pimpinan dan bawahan) untuk memperbesar efektivitas organisasi. Manajemen mencakup proses mental dan fisik yang mendorong orang lain untuk melaksanakan tugas resmi yang dipersyaratkan untuk mencapai sasaran organisasi.

Dalam konteks ini kepemimpinan merupakan proses pengaruh sosial yang mengikutsertakan bawahan dalam usaha pencapaian tujuan. Dengan demikian berarti bahwa memang ada implikasi bahwa pemimpin telah membawa perubahan dalam bawahan berperilaku. Pemimpin adalah ahli strategi yang menetapkan tujuan organisasi eksternal maupun internal (Dale Timpe, 1999:ix). Dalam teori ini ditegaskan bahwa kepemimpinan yang baik adalah kepemimpinan yang mampu membawa perubahan. Sebab pemimpin memiliki kekuasaan dan kewenangan untuk mempengaruhi orang lain.

\section{Manajerial}

Setiap organisasi/lembaga memerlukan manajemen yang berguna untuk mencapai tujuan, menjaga keseimbangan diantara tujuan-tujuan yang saling bertentangan, dan untuk mencapai efisiensi dan efektivitas. Manajemen sangat diperlukan dalam berbagai kehidupan untuk mengatur langkah-langkah yang harus dilaksanakan 
oleh seluruh elemen dalam suatu organisasi/lembaga. Oleh karena itu dalam proses manajemen diperlukan adanya proses perencanaan, pengorganisasian, penganggaran, dan pengawasan. Langkah-langkah manajemen ini diharapkan mampu menjaga keseimbangan tujuan-tujuan yang semula saling bertentangan. Disamping itu, juga dimaksudkan agar mereka yang terlibat dalam suatu organisasi/lembaga melakukan pekerjaan yang benar dengan cara yang benar. Pengertian manajemen telah banyak dikemukakan oleh para ahli antara lain James F. Stoner (1982: 8) menyatakan bahwa manajemen adalah proses perencanaan, pengorganisasian, pengarahan, dan pengawasan usaha-usaha para anggota organisasi, dan penggunaan sumber daya-sumber daya organisasi lainnya untuk mencapai tujuan organisasi yang telah ditetapkan. Disini James F. Stoner menekankan bahwa manajemen itu dititikberatkan pada proses maupun sistem. Oleh karena itu apabila dalam sistem maupun proses penyusunan perencanaan, sistem pengorganisasian, dan sistem pengawasan itu tidak baik, maka proses manajemen itu secara keseluruhan juga tidak baik. Dengan demikian proses pencapaian tujuan organisasi juga terganggu malah mungkin mengalami kegagalan.

Sementara itu Luther Gullick dalam Sulistya-Basuki (1993:191) menyatakan bahwa manajemen itu meliputi; perencanaan/planning, pengorganisasian/organizing, personalia/staffing, pelaksanaan/directing, koordinasi/ coordinating, pelaporan/reporting, dan penganggaran/ budgeting. Teori ini apabila dibanding dengan teori-teori manajemen yang lain, ternyata memiliki beberapa kelebihan. Dalam hal ini Luther Gullick lebih memerinci aktivitas-aktivitas yang harus dilaksanakan dalam kegiatan manajemen. Padahal penulis lain tidak memerinci sejauh itu, bahkan sebagian besar penulis menyebutkan bahwa fungsi manajemen itu meliputi kegiatan perencanaan, pengorganisasian, dan pengawasan.

Dari sisi lain, manajemen kecuali sebgai suatu sistem, juga dipandang sebagai ilmu, seni, dan sebagai profesi. Manajemen sebagai ilmu pengetahuan dikemukakan oleh T. Hani Handoko (1993:6) yang menyatakan bahwa dalam pelaksanaan manajemen diperlukan disiplin ilmu pengetahuan lain seperti ilmu ekonomi, ilmu komputer, akutansi, statistik, dan konsep-konsep yang cenderug benar dalam semua situasi manajerial.
Mengingat satu dan lain hal, maka dalam penelitian ini, manajemen dipandang sebagai ilmu pengetahuan karena dalam pelaksanaan manajemen perpustakaan diperlukan ilmu-ilmu lain seperti psikologi, statistik, teknologi informasi, matematika, dan lainnya. Dari hasil penelitian ini diharapkan dapat digunakan sebagai masukan bagi pimpinan perguruan tinggi dalam penetapan kepala perpustakaan di lembaga pendidikan tinggi yang mereka pimpin.

\section{METODE PENELITIAN}

Penelitian ini menggunakan metode deskriptif yakni suatu metode dalam meneliti status kelompok manusia, suatu obyek, suatu set kondisi, suatu sistem pemikiran, ataupun kelas peristiwa pada masa sekarang (Nazir, 1988: 63). Penelitian ini untuk membuat deskripsi gambaran maupun lukisan suatu keadaan secara sistematis, faktual, dan akurat mengenai beberapa fakta, beberapa sifat, serta hubungan antar fenomena yang diselidiki. Metode penelitian deskriptif ini merupakan metode yang banyak digunakan dan dikembangkan dalam penelitian ilmu-ilmu sosial karena memang kebanyakan ilmu sosial bersifat deskriptif (Nasution, 1982: 32). Meskipun demikian, metode penelitian ini dapat juga digunakan dalam penelitian ilmu-ilmu eksakta. Disamping itu metode ini banyak dipengaruhi oleh pemikiran-pemikiran yang berkembang dalam ilmu sosial.

Dalam hal penelitian deskriptif ini Saifuddin Azwar (1998:6) menjelaskan bahwa penelitian ini bertujuan untuk melakukan analisis hanya sampai pada taraf deskriptif yaitu menganilisis dan menyajikan fakta secara sistematis sehingga mudah dipahami dan disimpulkan.,

Penelitian ini dilaksanakan dengan obyek para pengelola, para pimpinan dan para pemakai perpustakaan PTN DIY yakni Universitas Gadjah Mada, Universitas Negeri Ygyakarta, Institut Agam Islam Negeri/IAIN Sunan Kalijaga, dan Institut Seni/ISI Yogyakarta.

Adapun populasi yang dijadikan sampel dalam penelitian ini meliputi 4 (empat) orang kepala perpustakaan PTN DIY, 63 orang terdiri dari para manajer madya dan pustakawan. Adapun populasi tentang pemanfaatan perpustakaan diambil 80 sampel pemakai dengan jumlah 
yang variatif sesuai dengan besar kecilnya perguruan tinggi. Mereka itu terdiri dari mahasiswa dan dosen sebagai pemakai jasa perpustakaan masing-masing perpustakaan PTN DIY.

Dalam penelitian ini digunakan metode pengumpulan data dengan cara wawancara, kuesioner, dokumentasi, dan metode studi pustaka. Wawancara merupakan metode pengumpulan data yang dilakukan melalui kontak pribadi dalam bentuk tatap muka antara pengumpul dengan responden. Interviu ini merupakan alat yang efektif untuk mengumpulkan data sosial berupa informasi tentang manusia dan segala sesuatu yang dipengaruhi oleh manusia (Hadari Nawawi, 1995: 98).

Kuesioner merupakan teknik pengumpulan data melalui formulir-formulir berisi pertanyaan yang diajukan kepada seseorang atau kelompok orang untuk mendapatkan informasi yang diperlukan (Mardalis, 1989: 67). Angket tertutup itu disebarkan kepada 63 orang pustakawan dan manajer menengah, dan 80 orang mahasiswa 4 (empat) PTN DIY itu. Pada pertanyaan tertentu akan dicari jawaban secara mendalam untuk memperoleh informasi yang lebih akurat. Studi kepustakaan dilakukan untuk menghindari adanya duplikasi penelitian dan untuk memperoleh teori, wawasan, dan perbandingan teori, rumusan, dan pandangan yang terkait dengan topik penelitian. Metode dokumentasi merupakan pencarian data tentang sesuatu hal yang berupa catatan, buku, notulen rapat, dan sebagainya (Suharsini Arikunto, 1991: 188). Dalam hal ini dikumpulkan catatan dan rekaman yang berkaitan dengan topik penelitian.

Dalam pengolahan data dimulai dengan pengumpulan data, lalu diseleksi untuk mengurangi kesalahan atau kekurangan. Pemeriksaản dan penyeleksian data ini dilakukan untuk mengetahui kelengkapan jawaban, keterbacaan tulisan, kejelasan makna jawaban, kesesuaian jawaban, relevansi jawaban, dan keseragaman satuan data. Setelah itu, kemudian dilakukan pengkodean yakni mengklarifikasikan jawaban-jawaban para responden ke dalam kategori-kategori. Kemudian jawaban-jawaban yang sudah diberi kode kategori itu dimasukkan ke dalam tabeltabel dengan cara: menghitung frekuensi data dalam masing-masing kategori jawaban, dan menyusun tabel dan distribusi frekuensi.

\section{PEMBAHASAN}

Kinerja sebenarnya merupakan hasil kerja yang dicapai oleh seseorang maupun kelompok dalam suatu lembaga/organisasi sesuai wewenang dan kemampuan masing-masing dalam rangka mencapai tujuan organisasi. Kinerja perorangan erat hubungannya dengan kinerja lembaga. Artinya apabila kinerja masing-masing individu di lembaga itu baik, maka kinerja lembaga itu juga baik. Sebalikya apabila hasil kerja yang ditunjukkan masingmasing individu di lembaga itu jelek, maka kinerja lembaga itu juga jelek.

Mereka yang bekerja di suatu lembaga akan mampu meningkatkan kinerja mereka apabila memiliki keahlian/ skill yang tinggi, gaji yang seimbang, dan memiliki harapan/ expectation masa depan yang lebih baik (Suyadi Prwirosentono, 1997:1). Dengan faktor-faktor tersebut mereka diharapkan mampu melakukan aktivitas dengan efektif dan efisien.

Kemudian dengan kemampuan yang tinggi dan kesediaan bekerja keras diharapkan dapat dicapai kinerja yang baik. Kinerja seperti yang diharapkan itupun harus didukung oleh faktor eksternal seperti pekerjaan mudah, nasib baik, bantuan dari rekan-rekan sekerja dan pimpinan yang baik. Sebaliknya apabila karyawan itu memiliki kemampuan yang rendah apalagi tidak mau bekerja keras, maka sulit diharapkan tercapainya kinerja yang baik. Apalagi apabila kondisi lingkungan tidak mendukung misalnya kepemimpinan buruk, rekan-rekan sekerja tidak mendukung, nasib buruk, maupun pekerjan sulit (Thomas S. Batman, 1999: 31)

Efektivitas kinerja perpustakaan tidak hanya ditentukan oleh penampilan fisik, tetapi juga perlu diperhatikan esensi perpustakaan itu sendiri. Disamping itu efektivitas suatu perpustakaan dapat diukur dari berbagai unsur dan dalam penelitian ini dibatasi pada peningkatan sumber daya manusia, peningkatan pelayanan, peningkatan fasilitas, dan suasana perpustakaan.

\section{Peningkatan Sumber Daya Manusia}

Secara umum sumber daya yang dimiliki oleh suatu perpustakaan terdiri dari sumber daya manusia/human resources dan sumber daya non manusia/non human 
resources. Sumber daya manusia dapat dilihat dari perspektif politik, ekonomi, kultural, maupun administrasi. Sumber daya manusia ini merupakan faktor yang paling dominan apabila dibanding dengan sumber daya-sumber daya yang lain dalam suatu perpustakaan. Sebab sumber daya manusia merupakan unsur utama dalam pencapaian keberhasilan suatu perpustakaan. Apalagi apabila keinginan-keinginan dan kebutuhan-kebutuhan mereka dapat terpenuhi secara wajar, maka mereka akan memberikan kontribusi demi keberhasilan organisasi. Oleh karena itu itu sumber daya manusia perlu ditingkatkan terus menerus antara lain melalui pendidikan formal, nonformal, dan informal. Peningkatan ini dimaksudkan untuk meningkatkan kepuasan karyawan, meningkatkan kinerja mereka, mengatasi kekurangan, dan meningkatkan kualitas kerja (Jo Bryson, 1990: 94). Upaya peningkatan sumber daya manusia di UPT Perpustakaan IAIN Sunan Kalijaga Yogyakarta yang terdiri dari pustakawan maupun non pustakawan sebanyak 23 orang $(44.68 \%)$ dari seluruh personalia-di UPT Perpustakaan IAIN Sunan Kalijaga. Kemudian peningkatan sumber daya manusia di UPT Perpustakaan ISI Yogyakarta sebanyak 4 orang (14.28\%) dari seluruh pustakawan dan nonpustakawan di lingkungan ISI Yogyakarta. Lain halnya dengan UPT Perpustakaan UGM selama periode kepemimpinan non pustakawan ternyata hanya mampu meningkatkan kualitas sumber daya manusia sebanyak 9 orang (7.62\%) dari seluruh tenaga (pustakawa \& nonpustakawan). Lalu peningkatan sumber daya manusia di UPT Perpustakaan UNY Yogyakarta sebanyak 9 orang (21.28\%) dari seluruh personalia.

\section{b. Peningkatan Sistem Pelayanan}

Perpustakaan sebagai sistem informasi kini menghadapi persoalan ekstern dan intern. Dalam skala ekstern perpustakaan menghadapi persaingan dalam pelayanan informasi, globalisasi, dan perubahan kebijaksanaan. Dalam skala intern, perpustakaan menghadapi masalah-masalah sikap pustakawan, manajerial, dan orientasi perpustakaan (Lasa Hs., 1999: 39)

Jasa pelayanan perpustakaan PTN DIY selama ini paling banyak diminati adalah sirkulasi, baca di tempat, dan baca skripsi. Pelayanan sirkulasi paling banyak diminati ditunjukkan dengan hasil angket responden di 4 (empat)
PTN masing-masing; IAIN (28.71\%), ISI (27.70\%), UGM (30\%), UNY (28.84\%) responden. Kemudian mereka yang membaca di tempat dengan hasil; IAIN (19.76\%), ISI (18.75\%), UGM (30\%), UNY 28.84\%). Kemudian untuk jasa baca fotokopi ditunjukkan degan hasil angket untuk IAIN (19.02\%), ISI (18.04\%), UGM (18.34\%) dan UNY $(17.30 \%)$.

\section{c. Peningkatan Fasilitas}

Pelayanan perpustakaan akan terselenggara dengan baik apabila ditunjang dengan fasilitas yang memadai seperti mebeler, mesin fotokopi, alat komunikasi, dan teknologi informasi. Sebagian besar perpustakaan PTN DIY belum mampu menyediakan fasilitas yang diharapkan. Hal ini dibuktikan dengan pengakuan responden untuk meningkatkan fasilitas perpustakaan sebanyak $81.71 \%$ responden UGM, $86.64 \%$ responden IAIN, $73.19 \%$ responden ISI, dan sebanyak $76.90 \%$ responden UNY.

\section{d. Peningkatan Suasana Yang Kondusif}

Perpustakaan sebagai tempat belajar memerlukan suasana yang kondusif untuk membaca, memahami, dan diskusi. Untuk itu di satu pihak memerlukan ruang yang tenang, sejuk, dan dengan mebeler yang ergonomis. Tetapi di pihak lain diperlukan ruang tersendiri untuk diskusi, internet, ruang audio visual, dan lainnya.

Suasana perpustakaan PTN DIY belum seperti yang diharapkan dan perlu peningkatan. Hal ini ditunjukkan dengan hasil angket masing-masing perpustakaan PTN DIY yang menunjukkan prosentasi tinggi, yakni IAIN (71.15\%), ISI (73.34 \%), UGM (68.43\%), UNY (76.96\%). Kemudian mereka yang menyatakan sudah kondusif cenderung rendah yakni IAIN (7.85 \%), ISI (5.46\%), UGM (10.52\%), UNY $(5.40 \%)$.

\section{PENUTUP}

Karena keterbatasan pengetahuan dan pengalaman para kepala perpustakaan PTN DIY tentang manajemen dan kepemimpinan, maka mereka kurang bisa menerapkan fungsi-fungsi manajemen di perpustakaan yang mereka pimpin. Adapun indikatornya antara lain; tidak memiliki perencanaan yang strategis dan hanya cenderung mengikuti 
rutinitas, visi dan misi yang dicanangkan kurang kompetitif, kurang koordinasi, kurang memberikan pengarahan. Pengawasan bawahan juga kurang, namun dalam pengawasan keuangan cukup baik.

Oleh karena itu para kepala perpustakaan prguruan tinggi seharusnya memahami manajemen dan kepemimpinan yang diperoleh dari pengalaman dan pendidikan formal dan nonformal.

Disamping itu, mengingat sistem pengangkatan kepala perpustakaan PTN DIY masih menganut penunjukan rektor/ top down, maka sering yang diangkat itu atas pertimbangan subjektif dan tidak didasarkan aspirasi bawahan/bottom up. Hal ini berakibat ketidak sesuaian mereka dengan lembaga yang mereka pimpin. Apalagi dijabat oleh mereka yang tidak memahami bidang perpustakaan. Untuk itu kepala perpustakaan perlu dijaring dari bawah, menguasai bidang perpustakaan, dan mampu memenej perpustakaan, dan memiliki jiwa kepemimpinan yang baik.

Kecuali itu, manajerial dan kepemimpinan antara pustakawan dan nonpustakawan memiliki kekurangan masing-masing. Manajerial pustakawan sangat berpengaruh pada penetapan visi dan misi dan peningkatan sumber daya manusia. Akan tetapi dalam perencanaan secara keseluruhan dan manajemen sumber daya manusia rata-rata lemah.

Kemudian kepemimpinan pustakawan sangat berpengaruh pada kepedulian sosial, peningkatan kinerja dan rotasi kerja. Mereka kurang dalam pengambilan keputusan dan harmonisasi hubungan atasan bawahan.

Kepemimpinan nonpustakawan atau rangkap jabatan (jabatan kepala perpustakaan dan jabatan fungsional dosen) sangat berpengaruh pada dorongan peningkatan kerja dan kepuasan kerja. Akan tetapi dalam beberapa hal menunjukkan kelemahan seperti dalam pengambilan keputusan, pendelegasian wewenang, kepedulian sosial, pemberian pengarahan, dan kurang melibatkan bawahan dalam pengambilan keputusan.

Sementara itu manajerial nonpustakawan kurang dalam hal perencanaan pengembangan perpustakaan, penyusunan visi dan misi, dan perencanaan stratejik

\section{Daftar Pustaka}

Apostle, Richard. 1997. Librarianship and the Information Paradigm. London: The Scarecrow Press

Arikunto, Suharsini. 1993. Prosedur Penelitian; Suatu Pendekatan Praktek. Jakarta Rineka Cipta

Azwar, Saifuddin. 1997. Metode Penelitian. Yogyakarta: Pustaka Pelajar

Batman, Thomas S. 1999. "Mengapa di Balik Individu" dalam "Kinerja" oleh Dale A. Timpe. Jakarta: PT. Elex Media

Blagden, John. 1980. Do We Really Need Libraries?. New York: K.G. Saur \& Clive Bingley

Boyce, Bert R. 1994. Measurements in Information Science. New York: Academic Press

Bryson, Jo. 1994. Effective Library and Information Centre Management. Hants England: Gower Publ. Co.

Busha, Robi. 1980. Research Methods in Librarianship. New York: Academic Press

Handoko, T. Hani. 1993. Manajemen. Yogykarta: BPFE

Hughes, Owen E. 1994. Public Management and Administration. New York: ST Marten Press

Lasa Hs. Menatap Wajah Perpustakaan Perguruan Tinggi Kita. Buletin FKP2T, 1 (2) Juni-November 1995: 18-24. Line, Maurice. 1989. Academic Library Management. Library Association

Lock, R.N. 1973. Library Administration. London: Crosby Locjwood and Son.

McConkey, Dale D. 1982. Manajemen Bagi Organisasi Nonperusahaan. Jakarta: Binaman Pressindo

McLeod, Raymond. 1995. Sistem Informasi Manajemen. Jakarta: PT Prehilindo

Nawawi, Hadari, 1993. Kepemimpinan Menurut Islam. Yogyakarta: Gadjah Mada University Press

-..-. 2000. Kepemimpinan Yang Efektif.

Yogyakarta: Gadjah Mada University Press

Nazir. 1988. Metode Penelitian. Jakarta, Ghalia Indonesia Powel, Ronald R. 1991. Basic Research Methods for Librarians. New Jersey: Ablex Publ. Co. 
Prawirosentono, Suyadi. 1999. Kebijakan Kinerja Karyawan. Yogyakarta: BPFE

Shera, Jesse H. 1978. Foundation of Education for Librarianship. New York: baecker and Hayes

Sulistyo-Basuki, 1993. Pengantar Ilmu Perpustakaan. Jakarta: PT Gramedia Pustaka Utama.

Swastha, basu. 1996. Azas-azas Manajemen Modern. Yogyakarta: Liberty.

Timpe, Dale. 1994. Kepemimpinan/Leadership. Jakarta: PT. Elex Media

Zen, Zulfikar, 2000. Pustakawan Fungsional Versus Struktural dan Ketidakadilan. Marsela, II (2) April 200.

Zorkoezy, Peter. 1995. Information Technology.London Pitman Publ. 